\title{
Isolated Intracranial Rosai-Dorfman Disease Involving the Meninges: Report of a Rare Case
}

\author{
Meninksleri Tutan İole Intrakraniyal Rosai-Dorfman Hastallğı: \\ Nadir Bir Olgu Suпumu
}

\author{
Amoolya BHAT, Shivakumar S. KUPANUR, Geethamani V \\ Sapthagiri Institute of Medical Sciences and Research Center, Department of Pathology, Karnataka, India
}

Corresponding Author: Amoolya BHAT / E-mail: amoolyabhat@rediffmail.com

\begin{abstract}
Sinus histiocytosis with massive lymphadenopathy or Rosai-Dorfman disease (RDD) is a reactive condition of unknown etiology, characterised by a proliferation of histiocytes exhibiting emperipolesis of lymphocytes and plasma cells. It usually presents as bilateral painless cervical lymphadenopathy. Extranodal RDD without nodal disease is seen in 23\% of the cases. Intracranial RDD occurs in less than $5 \%$ of the total number of patients with extranodal disease. Isolated intracranial RDD in the absence of nodal disease is exceptional.

We report a case of Rosai-Dorfman disease with isolated intracranial involvement. A 38-year-old man came with long-standing headache and the magnetic resonance imaging (MRI) scan showed features of meningioma. The histopathology revealed sheets of histiocytes displaying emperipolesis. These histiocytes were S100 positive but CD1a and epithelial membrane antigen negative.
\end{abstract}

KEYWORDS: Emperipolesis, Extranodal Rosai-Dorfman disease, Intracranial Rosai-Dorfman disease, Sinus histiocytosis with massive lymphadenopathy

öz

Masif lenfadenopatili sinüs histiyositozu veya Rosai-Dorfman hastalığı (RDD) bilinmeyen etiyolojili reaktif bir durumdur ve lenfositler ve plazma hücrelerinin emperipolezisini gösteren bir histiosit proliferasyonuyla karakterizedir. Genellikle bilateral ağrısız servikal lenfadenopati olarak ortaya çıkar. Nodal hastalık olmadan ekstranodal RDD olguların \%23'ünde görülür. Intrakraniyal RDD, ekstranodal hastalıklı hastaların \%5'inden azında görülür. Nodal hastalık bulunmadığında izole intrakraniyal RDD çok nadirdir.

İzole intrakraniyal tutulumlu bir Rosai-Dorfman hastalığı olgusu sunuyoruz. 38 yaşında bir erkek, uzun süreli baş ağrısı ile başvurdu ve manyetik rezonans görüntüleme (MRG) taraması menenjiyom bulguları gösterdi. Histopatolojide emperipolez gösteren histiyosit tabakaları görüldü. Bu histiyositler S100 pozitif ama CD1a ve epitelyal membran antijeni negatifti.

ANAHTAR SÖZCÜKLER: Emperipolez, Ekstranodal Rosai-Dorfman hastalığı, İntrakraniyal Rosai-Dorfman hastalığı, Masif lenfadenopatili sinüs histiyositozu

\section{INTRODUCTION}

Rosai-Dorfman disease (RDD) is characterized by bilateral cervical lymphadenopathy fever, leukocytosis, increased erythrocyte sedimentation rate and hypergammaglobulinaemia. Extranodal involvement occurs with lymphadenopathy in $43 \%$ of the cases. Isolated extranodal disease occurs in about $23 \%$ of the cases and affects skin (12\%), paranasal sinuses $(11 \%)$, soft tissues $(9 \%)$, bone $(9 \%)$, salivary glands $(5 \%)$, central nervous system (5\%), oral cavity (3\%), kidney (2\%), lower respiratory tract $(2 \%)$, larynx $(1 \%)$ and orbit $(5-10 \%)(5,8,9)$.

Due to its rarity, RDD is never a first diagnosis in intracranial lesions. It mimics meningioma, neurosarcoidosis, and metastasis radiologically. Histopathologically, it mimics plasma cell granuloma, fungal granulomas and lymphoplasmacyterich meningiomas. Immunohistochemistry and special stains play a crucial role whenever the classical emperipolesis is infrequent.

\section{CASE REPORT}

A 38-year-old male presented with headache for six months. There was no history of seizure, lymphadenopathy, hepatosplenomegaly, visual defects or neurological deficits. There was no significant past history. Complete blood count was normal. Erythrocyte sedimentation rate was $16 \mathrm{~mm}$ per hour.

Magnetic resonance imaging (MRI) showed an isointense, extra axial, space-occupying lesion in the posterior parietal convexity; measuring $5.5 \times 1.5 \mathrm{~cm}$ with homogenous contrast enhancement and enhancing dural tail. There was mild to moderate perilesional edema and mass effect (Figure 1A,B). Meningioma, glioma, syphilis, tuberculosis, sarcoidosis, metastasis were the preoperative diagnoses.

Urine analysis, liver and renal function tests, chest X-ray and ultrasonography of the abdomen were unremarkable. 
Cerebrospinal fluid (CSF) analysis was unremarkable. Venereal disease research laboratory (VDRL) test and Mantoux tests were negative. Tests for HIV and HBS Ag were negative. Intraoperatively, the tumor was yellowish in color and surrounded by congested meninges. The lesion was excised.

The tumor measured $5.5 \times 5 \times 1.5 \mathrm{~cm}$, and the cut surface was lobulated and yellow (Figures 2A,B). Microscopy showed a lobulated lesion composed of sheets of histiocytes, plasma cells and mature lymphocytes separated by fibrous septae (Figure 2C). Histiocytes were the predominant cells and contained abundant pale to vacuolated cytoplasm and mildly pleomorphic vesicular nuclei with multiple prominent nucleoli. Emperipolesis of lymphocytes, plasma cells and neutrophils was seen (Figures 2D; $3 A-C$ ). Plasma cells
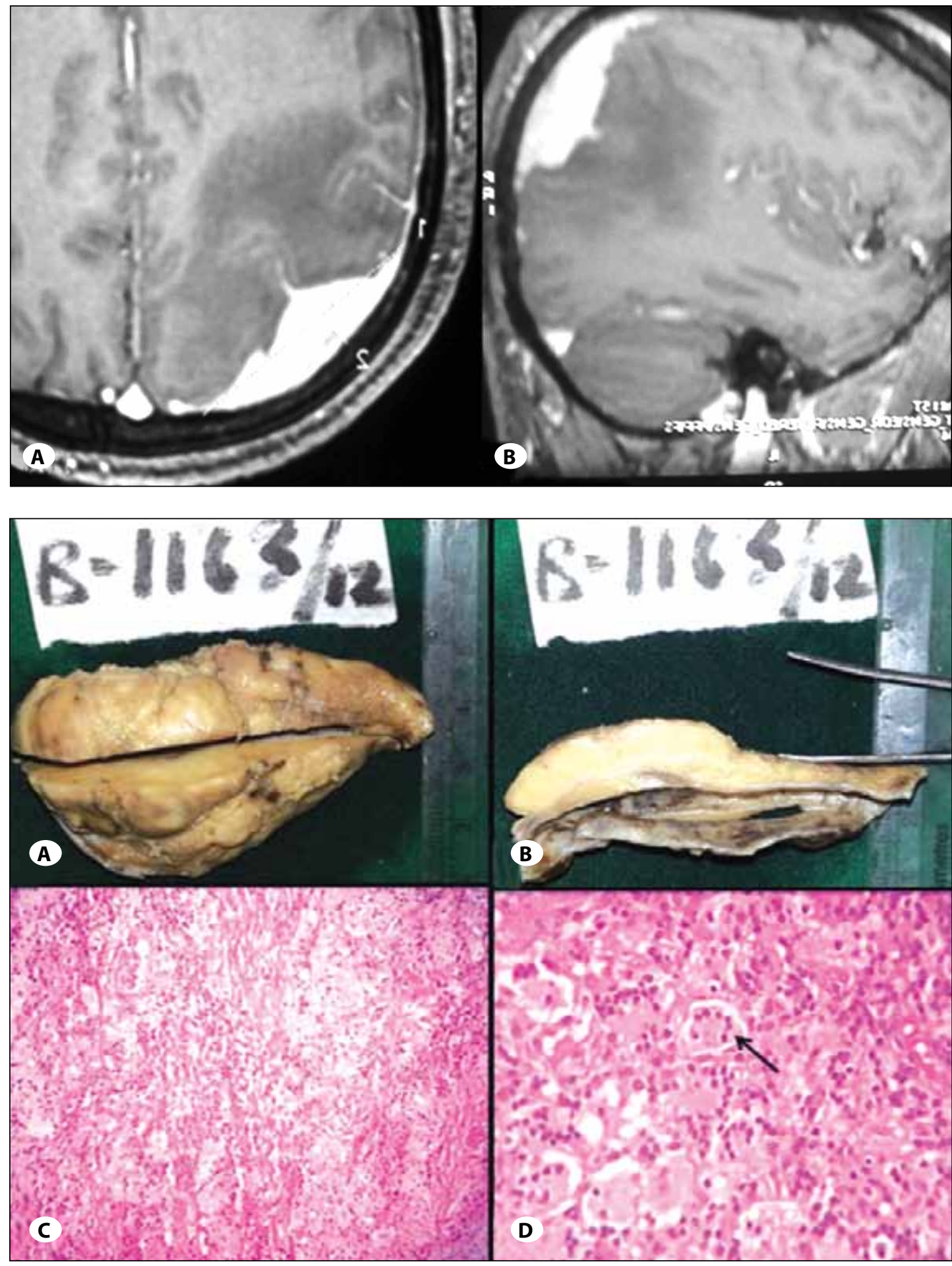

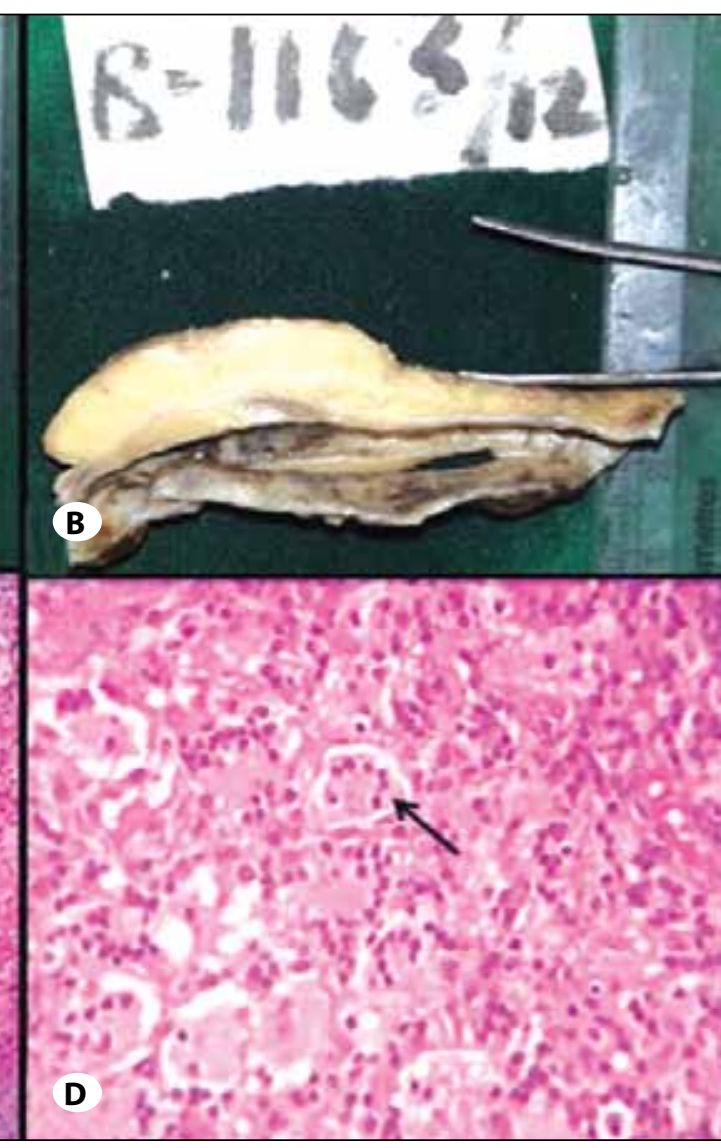

Figure 1: A) Axial, B) sagittal contrast MRI showing enhancing extra-axial space occupying lesion of dura in the posterior parietal convexity with mass effect and dural tail. Perilesional edema is also noted.

Figure 2: A) External surface showing nodular lesion involving the dura. B) Cut-section showing homogenous yellowish lobulated appearance. C) Section showing fibrous septae separating the histiocytic nodules ( $H$ and $E ; \times 100)$. D) Sections showing emperipolesis (arrow) of lymphocytes by histiocytes ( $\mathrm{H}$ and $\mathrm{E}$; $\mathrm{x} 100$ ). 


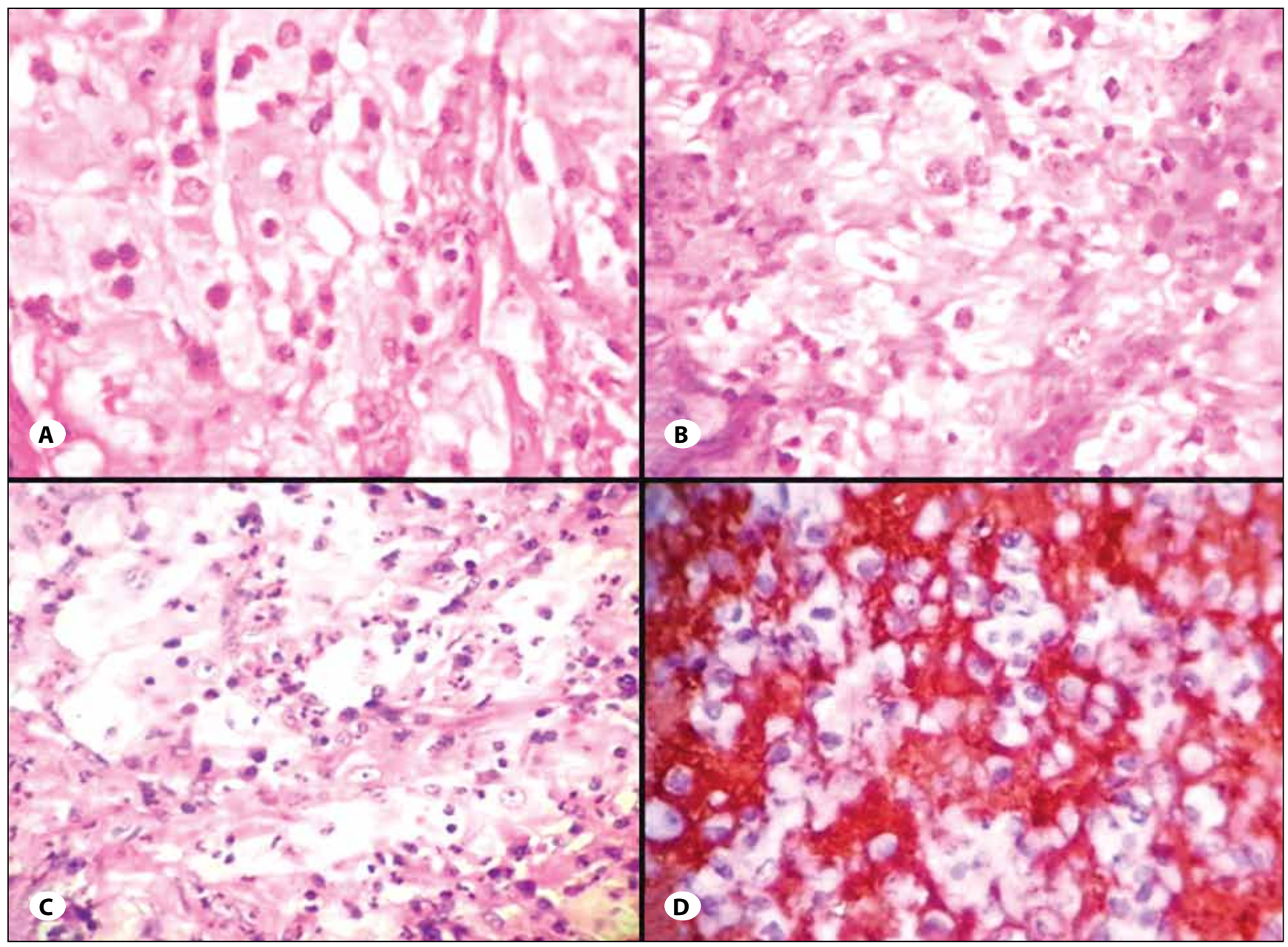

Figure 3: A) Section showing emperipolesis of neutrophils and lymphocytes by histiocytes (H and $E, x 400)$. B, C) Sections showing mild nuclear atypia and multiple nucleoli in histiocytes (H and E; X400). D) Immunohistochemistry showing strong cytoplasmic $S 100$ positivity in histiocytes (IHC S100; x400).

appeared mature with an eccentric cartwheel-type nucleus and Russell bodies. No eosinophils, epithelioid granulomas, necrosis, psammoma bodies, whorl formation or mitotic figures noted.

Lymphomas and plasmacytomas were unlikely considering the lack of monotonous atypical lymphocytes and plasma cells. Rosai-Dorfman disease, Langerhans histiocytosis, lymphoplasmacyte-rich meningioma, plasma cell granuloma, fungal granulomas, and idiopathic pachymeningitis were considered in differential diagnoses. Acid-fast stain, Periodic acid Schiff (PAS) and Grocott Methenamine Silver (GMS) stains were negative. Immunohistochemistry (IHC) using epithelial membrane antigen (EMA), S 100 and CD1a showed diffuse cytoplasmic S100 positivity in histiocytes (Figure 3D). EMA and CD1a were negative. Thus a final diagnosis of Rosai-Dorfman disease of the meninges was made.

Whole body CT scan ruled out the presence of nodal disease and malignancy.

\section{DISCUSSION}

Sinus histiocytosis with massive lymphadenopathy or RosaiDorfman disease is a reactive condition of unknown etiopathology, characterised by a proliferation of histiocytes that exhibit emperipolesis of lymphocytes and plasma cells. At present, it is considered a benign or reactive proliferation showing spontaneous regression. It usually presents as bilateral painless cervical lymphadenopathy. Intracranial RDD occurs in less than $5 \%$ of the cases and the dura is the most common site of involvement $(5,9)$. Systemic symptoms may be absent in isolated intracranial disease. The treatment options range from surgery, radiotherapy and steroids to chemotherapy.

The present case came with a long-standing headache. Signs of meningitis and neurological deficits were absent. Meningiomas and idiopathic pachymeningitis were the possible clinical diagnoses. Although radiologically it mimicked meningiomas and inflammatory diseases, complete blood count, serological tests and CSF analysis ruled out infectious 
diseases. Immunohistochemistry and special stains ruled out the various histological differential diagnoses.

Lymphoplasmacyte-rich (LPR) meningiomas show proliferation of meningothelial cells which may be masked by dense infiltrations of lymphocytes and polyclonal plasma cells. S100 and EMA highlight the meningothelial cells (6). Radiologically isointensity, contrast enhancement and perilesional edema are common to both LPR meningiomas and RDD. Although vesicular nuclei and prominent nucleoli of histiocytes resembled the reactive meningothelial cells in our case, they lacked EMA positivity and showed emperipolesis.

Langerhans cell histiocytoses show a mixture of histiocytes, multinucleate giant cells, plasma cells, eosinophils, lymphocytes, and neutrophils. Langerhans histiocytes have a characteristic indented or grooved nucleus that contains delicate chromatin and inconspicuous nucleoli. Occasionally, in aggressive cases, they demonstrate prominent nucleoli. The CD1a is strongly positive in these tumors (3).

Fungal lesions show granulomas and necrosis. PAS and GMS stains show fungal hyphae.

Plasma cell granulomas are characterized by loosely arranged plump or spindled myofibroblasts in an oedematous myxoid background with abundant blood vessels and an infiltrate of polyclonal plasma cells, lymphocytes, and eosinophils. Atypical forms show polygonal cells with vesicular nuclei and prominent nucleoli. They lack S100 positivity and emperipolesis $(1,4)$.

Idiopathic hypertrophic pachymeningitis (IHP) shows thickened fibrotic dura with chronic inflammatory infiltration composed of lymphocytes, plasma cells and histiocytes. Radiologically these lesions mimic meningiomas (2). They do not show emperipolesis and S 100 positive histiocytes.

Patients with Langerhans histicytoses have a favorable prognosis but recurrence and erosion of skull bones are frequent. Plasma cell granulomas are benign non-recurrent conditions but local aggressiveness and recurrence may complicate the outcome of disease (1). Fungal infections need anti fungal therapy. Idiopathic hypertrophic pachymeningitis requires long-term maintenance therapy with corticosteroids and can recur or spread contiguously, leading to neurological deficits if untreated (2).

Isolated intracranial Rosai-Dorfman disease is a benign disease with good prognosis. Recurrence and development of neurological deficits is rare. Surgical resection is the best modality of therapy. The lesion is extremely radiosensitive. Progressive disease and nonresectable lesions are treated with radiotherapy and chemotherapy (5). Radiological findings may be unusual at times. Rare cases show erosion of skull bone or subarachnoidal space (7). Post surgical complications such as bleeding may occur when the lesions are highly vascular as shown radiologically by perilesional edema (9).

\section{CONCLUSIONS}

Although isolated intracranial Rosai Dorfman disease is rare, it should be included in the differential diagnosis of a dural mass that resembles meningioma. Histologically, it mimics several neoplastic and non-neoplastic lesions especially when emperipolesis is infrequent and nodal disease is not evident. Special stains and immunohistochemistry are needed for definitive diagnosis as the prognosis and treatment aspects differ for the various differential diagnoses.

\section{REFERENCES}

1. Coffin CM, Fletcher JA: Inflammatory myofibroblastic tumor. In: Fletcher CDM, Unni KK, Mertens F (ed), World Health Organization Classification of Tumours. Pathology and Genetics of Tumours of Soft Tissue and Bone. Lyon: IARC Press, 2002: 91-93

2. Hosler MR, Turbin RE, Cho ES, Wolansky LJ, Frohman LP: Idiopathic hypertrophic pachymeningitis mimicking lymphoplasmacyte rich meningioma. J Neuro-Ophthalmol 27:95-98, 2007

3. Konishi E, Ibayashi N, Yamamoto S, Scheithauer BW: Isolated intracranial Rosai-Dorfman Disease (Sinus Histiocytosis with Massive Lymphadenopathy). Am J Neuroradiol 24:515-518, 2003

4. Kumar R, Giri PJ, Jaiswal A, Agarwal T, Pal L: Intracranial Rosai-Dorfman syndrome mimicking meningioma. Pan Arab Journal of Neurosurgery 12:70-72, 2008

5. Krishnamoorthy V, Parmar CF, Panikar D: Isolated intracranial Rosai Dorfman disease. Neurology India 59:443-446, 2011

6. Nohara H, Furuya K, Kawahara N, lijima A, Yaka K, Shibahara J, Kirino T: Lymphoplasmacyte- rich meningioma with atypical invasive nature. Neurol Med Chir 47:32-35, 2007

7. Rodriguez-Galindo C, Helton KJ, Sánchez N D, Rieman M, Jeng M, Wang W: Extranodal Rosai-Dorfman disease in children. J Pediatr Hematol Oncol 26:19-24, 2004

8. Tavangar SM, Mahta A, Haghpanah V, Larjani B: Extranodal Rosai-Dorfman disease involving the meninges in a 79-yearold man. Ann Saudi Med 26:474-476, 2006

9. Tomio R, Katayama M, Takanaka N, Imanishi T: Complications of surgical treatment of Rosai-Dorfman disease: A case report and review. Surg Neurol Int 3:1, 2012 